CRYSTALLOGRAPHIC COMMUNICATIONS

ISSN 2056-9890

Received 27 October 2017

Accepted 17 November 2017

Edited by C. Massera, Università di Parma, Italy

₹ Currently at Max Planck Institute for Chemical Energy Conversion, Stiftstrasse 34-36, 45470

Mülheim an der Ruhr, Germany.

Keywords: crystal structure; in situ cryocrystallization; fluorine-based interactions; intermolecular interaction energies; Hirshfeld surface analysis.

CCDC reference: 1578858

Supporting information: this article has supporting information at journals.iucr.org/e

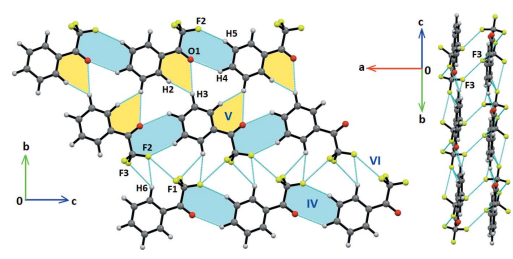

OPEN $\odot$ ACCESS

\section{Crystal packing analysis of in situ cryocrystallized 2,2,2-trifluoroacetophenone}

\author{
Dhananjay Dey, Abhishek Sirohiwal‡ and Deepak Chopra*
}

Crystallography and Crystal Chemistry Laboratory, Department of Chemistry, Indian Institute of Science Education and Research Bhopal, Bhopal 462066, Madhya Pradesh, India. *Correspondence e-mail: dchopra@iiserb.ac.in

Crystals of the liquid compound 2,2,2-trifluoroacetophenone (TFAP, $\mathrm{C}_{8} \mathrm{H}_{5} \mathrm{~F}_{3} \mathrm{O}$ ) were obtained using the state-of-art in situ cryocrystallization technique. TFAP crystallizes in the monoclinic space group $C 2 / c$, and its crystal structure is mainly stabilized by a set of $\mathrm{C}-\mathrm{H} \cdots \mathrm{F}, \mathrm{C}-\mathrm{H} \cdots \mathrm{O}, \mathrm{F} \cdots \mathrm{F}$ and $\mathrm{F} \cdots \mathrm{O}$ supramolecular contacts. The overall molecular arrangement shows the formation of molecular sheets parallel to the $b c$ plane, which are in turn stacked along the $a$-axis direction. The weak interactions have been studied thoroughly, performing both a Hirshfeld surface analysis and theoretical calculations, to obtain the intermolecular interaction energies. A structural comparison of this compound with the previously reported substituted analogs was also carried out, showing a qualitative difference in terms of packing behaviour.

\section{Chemical context}

The use of green, efficient, metal-free and inexpensive catalysts is the desire of every synthetic laboratory. The importance of metal-free catalysts is well known among synthetic chemists. In this class of catalysts, 2,2,2-trifluoroacetophenone (TFAP) is well known, because it is cheap and commercially available.

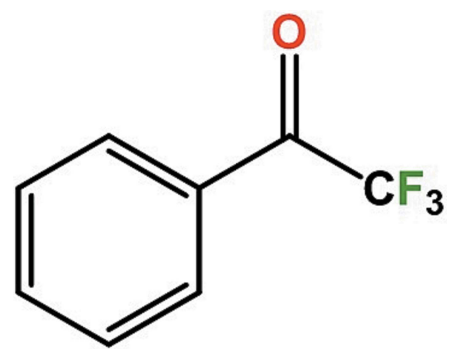

Research work in recent years has shown that TFAP can be used as a green organocatalyst in synthetic procedures, e.g. for the epoxidation of alkenes (Limnios \& Kokotos, 2014a), the oxidation of allyloximes to form isoxazoline (Triandafillidi \& Kokotos, 2017), the oxidation of aliphatic tertiary amines and azines (Limnios \& Kokotos, 2014b) and for the synthesis of substituted tetra-hydrofurans (Theodorou \& Kokotos, 2017a), indolines and pyrrolidines (Theodorou \& Kokotos, 2017b), besides being used for the synthesis of fluorinated polymers (Guzmán-Gutiérrez et al., 2008). Interestingly, TFAP has been also used for probing intermolecular interactions involved in the bi-molecular complexes formed on $\mathrm{Pt}(111)$ surfaces (Goubert et al., 2011). In fact, TFAP is also an excellent example to study the enantioselective hydrogenation on $\mathrm{Pt}$ 
Table 1

Hydrogen-bond geometry $\left(\AA,^{\circ}\right)$.

\begin{tabular}{lllll}
\hline$D-\mathrm{H} \cdots A$ & $D-\mathrm{H}$ & $\mathrm{H} \cdots A$ & $D \cdots A$ & $D-\mathrm{H} \cdots A$ \\
\hline $\mathrm{C} 6-\mathrm{H} 6 \cdots \mathrm{F} 1$ & 0.95 & 2.48 & $3.004(2)$ & 115 \\
$\mathrm{C} 6-\mathrm{H} 6 \cdots \mathrm{F} 3$ & 0.95 & 2.55 & $3.088(2)$ & 116 \\
$\mathrm{C} 5-\mathrm{H} 5 \cdots \mathrm{F} 2^{\mathrm{i}}$ & 0.95 & 2.63 & $3.522(2)$ & 156 \\
$\mathrm{C} 4-\mathrm{H} 4 \cdots \mathrm{O} 1^{\mathrm{i}}$ & 0.95 & 2.74 & $3.490(2)$ & 136 \\
$\mathrm{C} 6-\mathrm{H} 6 \cdots \mathrm{F} 2^{\mathrm{ii}}$ & 0.95 & 2.69 & $3.614(2)$ & 163 \\
$\mathrm{C} 6-\mathrm{H} 6 \cdots \mathrm{F} 3$ & & & \\
ii & 0.95 & 2.94 & $3.584(2)$ & 126 \\
$\mathrm{C} 5-\mathrm{H} 5 \cdots \mathrm{F} 3$ & & & \\
$\mathrm{C} 3-\mathrm{H} 3 \cdots \mathrm{O} 1^{\mathrm{iii}}$ & 0.95 & 2.98 & $3.603(2)$ & 124 \\
& 0.95 & 2.95 & $3.882(2)$ & 166
\end{tabular}

Symmetry codes: (i) $x, y, z-1$; (ii) $x,-y+1, z-\frac{1}{2}$; (iii) $x,-y, z-\frac{1}{2}$.

surfaces (Cakl et al., 2011). Keeping in mind both the important applications of this molecule and our work on intermolecular interactions involving organic fluorine, we decided to determine the crystal structure of this compound. It is worth noting that since TFAP is a liquid at room temperature, a crystal structure determination using conventional methods is not feasible; hence, this class of compounds needs special experimental settings. The method for obtaining crystals of these compounds is called the in situ cryocrystallization technique (Boese et al., 2003; Choudhury et al., 2005). In the recent past, we have employed this technique to obtain crystal structures of both organic (Dey et al., 2016a,b) and organometallic liquids (Sirohiwal et al., 2017a). We believe that this study delineates the importance of fluorine-based interactions, in addition to other weak interactions, which play a role in the crystal packing of TFAP.

\section{Computational methodology}

All the calculations were performed at the crystal geometry, where hydrogen-atom positions are fixed to their respective neutron values (Allen, 1986). The lattice and intermolecular interaction energies were computed using the PIXELC module of the CLP program (Version 12.5.2014; Gavezzotti, 2003, 2011), which partitions the total energy into Coulombic,

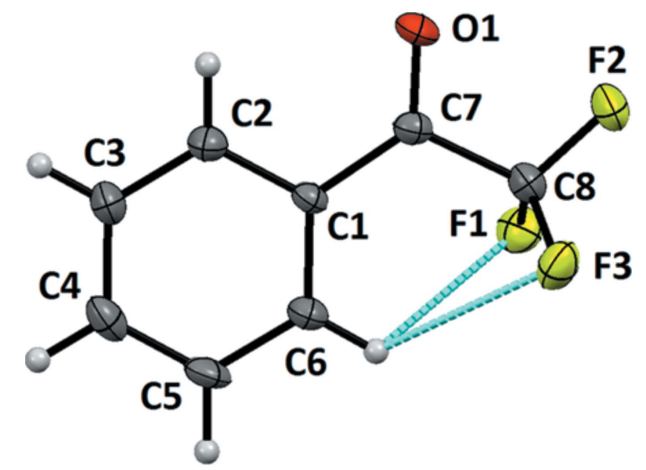

Figure 1

Displacement ellipsoid plot of TFAP drawn at the $50 \%$ probability level. Weak intramolecular interactions are shown as cyan dotted lines.

polarization, dispersion and repulsion energies. For the same purpose, the molecular electron density was computed at the MP2/6-31G (d, p) level of theory using Gaussian09 (Frisch et al., 2009).

\section{Structural commentary and supramolecular features}

The single-crystal X-ray diffraction analysis reveals that the title compound crystallizes in the space group $C 2 / c$, and confirms the presence of one $-\mathrm{COCF}_{3}$ functional group attached to the phenyl ring (see Fig. 1). The backbone of the molecule formed by the atoms $\mathrm{O} 1 / \mathrm{C} 1-\mathrm{C} 8$ is essentially planar, with a maximum deviation from the plane of 0.053 (1) $\AA$ for C8. In the molecule, two intramolecular $\mathrm{C}-\mathrm{H} \cdots \mathrm{F}$ interactions are present, involving $\mathrm{C} 6-\mathrm{H} 6$ and the atoms $\mathrm{F} 1$ and

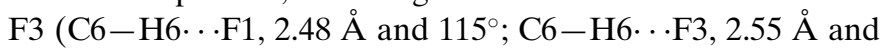
$116^{\circ}$; Table 1). A total of seven molecular pairs are extracted from the crystal packing based on their stabilizing contribution towards the total lattice energy. Their detailed energy decomposition analysis is listed in Table 2. These molecular pairs are associated through various intermolecular interactions involving aromatic $\mathrm{C}-\mathrm{H}$ groups as donors and $\mathrm{C}-\mathrm{F}$ and $\mathrm{C}=\mathrm{O}$ moieties as acceptors. The crystal packing is further

Table 2

Stabilization energies (in $\mathrm{kJ} \mathrm{mol}^{-1}$ ) of the individual molecular pairs.

$\mathrm{CD}=$ centroid-centroid distance.

\begin{tabular}{|c|c|c|c|c|c|c|c|c|c|}
\hline Motif & Symmetry & $\mathrm{CD}(\AA)$ & $E_{\text {Coul }}$ & $E_{\mathrm{Pol}}$ & $E_{\text {Disp }}$ & $E_{\text {Rep }}$ & $E_{\text {Tot }}$ & Possible Interactions & Geometry $\left(\AA,^{\circ}\right)$ \\
\hline I & $-x+1, y,-z+\frac{3}{2}$ & 3.731 & -5.6 & -1.7 & -26.2 & 14.6 & -18.8 & $\begin{array}{l}\mathrm{C} 7 \cdots \mathrm{C} 6 \\
\mathrm{C} 1 \cdots \mathrm{C} 1 \\
\mathrm{C} 2 \cdots \mathrm{C} 2 \\
\mathrm{C} 8-\mathrm{F} 3 \cdots \mathrm{F} 3-\mathrm{C} 8\end{array}$ & $\begin{array}{l}3.6668(1) \\
3.6035(1) \\
3.5545(1) \\
2.8743(1), 139,139\end{array}$ \\
\hline II & $-x+\frac{1}{2},-y+\frac{1}{2},-z+1$ & 5.470 & -3.5 & -0.9 & -20.4 & 10.2 & -14.5 & $\begin{array}{l}\pi-\pi \text { stacking } \\
\mathrm{C} 8-\mathrm{F} 1 \cdots \mathrm{C} 4\end{array}$ & $\begin{array}{l}3.7869 \text { (1) } \\
3.2425(1), 134\end{array}$ \\
\hline III & $-x+\frac{1}{2},-y+\frac{1}{2},-z+2$ & 5.274 & -5.2 & -1.5 & -12.6 & 6.7 & -12.7 & $\begin{array}{l}\mathrm{C} 7-\mathrm{O} 1 \cdots \mathrm{F} 2-\mathrm{C} 8 \\
\mathrm{C} 7-\mathrm{O} 1 \cdots \mathrm{F} 1-\mathrm{C} 8\end{array}$ & $\begin{array}{l}3.1436(1), 100,96 \\
3.0457,139,90\end{array}$ \\
\hline V & $x,-y, z+\frac{1}{2}$ & 8.524 & -1.3 & -2.3 & -10.0 & 6.8 & -6.9 & $\begin{array}{l}\mathrm{H} 3 \cdots \mathrm{H} 2 \\
\mathrm{C} 3-\mathrm{H} 3 \cdots \mathrm{O} 1\end{array}$ & $\begin{array}{l}2.40 \\
2.95,165\end{array}$ \\
\hline VI & $x,-y+1, z+\frac{1}{2}$ & 6.652 & -0.7 & -0.8 & -8.2 & 3.7 & -6.0 & $\begin{array}{l}\mathrm{C} 6-\mathrm{H} 6 \cdots \mathrm{F} 2 \\
\mathrm{C} 6-\mathrm{H} 6 \cdots \mathrm{F} 3 \\
\mathrm{C} 8-\mathrm{F} 1 \cdots \mathrm{F} 2-\mathrm{C} 8\end{array}$ & $\begin{array}{l}2.69,163 \\
2.94,124 \\
3.1023,114,147\end{array}$ \\
\hline
\end{tabular}




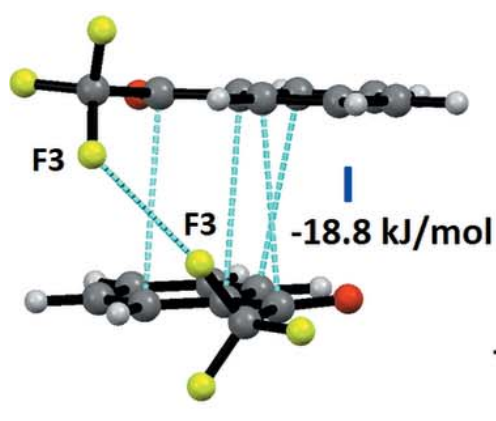

(a)

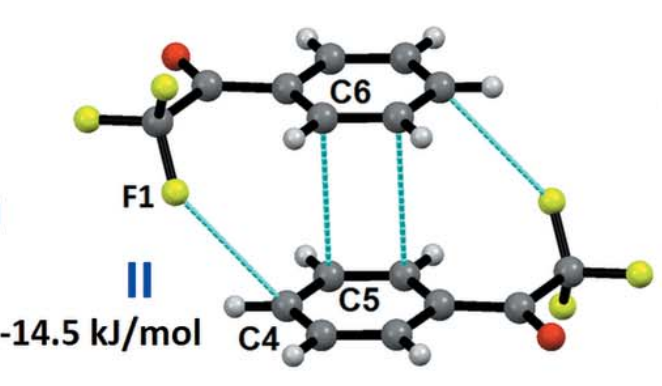

(b)

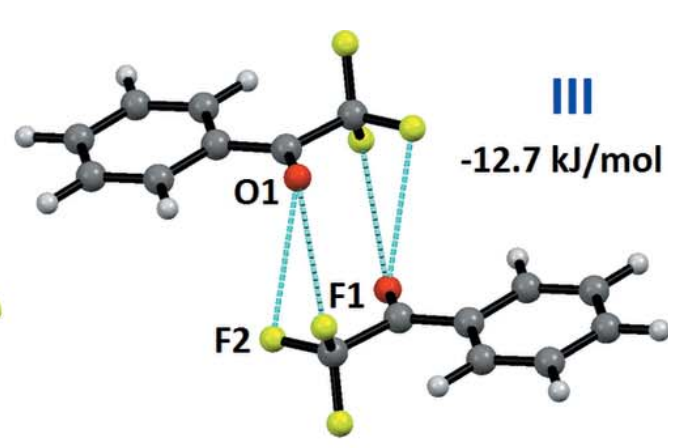

(c)

Figure 2

Molecular pairs (a) I, (b) II, and (c) III with their stabilization energies.

stabilized by the presence of $\pi-\pi$ stacking and of different types of atom-atom contacts, such as intermolecular F...F, $\mathrm{F} \cdot \mathrm{O}$, and $\mathrm{H} \cdots \mathrm{H}$ contacts.

The strongest molecular pair I (Fig. 2a), with an interaction energy of $-18.8 \mathrm{~kJ} \mathrm{~mol}^{-1}$, is formed via molecular stacking interactions and intermolecular type I F..F contacts [F3...F3, 2.8743 (1) $\AA$ and C8-F3 . F F3 139 $]$. In this case, the dispersion contribution (78\%) is more significant in comparison to the electrostatic contribution towards the total stabilization of the dimer. The centrosymmetric molecular pair II (Fig. $2 b$ ), which is also formed due to $\pi-\pi$ stacking, and to intermolecular $\mathrm{F} 1 \cdots \mathrm{C} 4$ interactions, shows an interaction energy of $-14.5 \mathrm{~kJ} \mathrm{~mol}^{-1} \quad(18 \%$ electrostatic and $82 \%$ dispersion contribution). Motif III (involving O1 with F1 and $\mathrm{F} 2$ ), with an interaction energy of $-12.7 \mathrm{~kJ} \mathrm{~mol}^{-1}$, is stabilized via intermolecular bifurcated F...O interactions with individual distances of 3.1436 (1) and $3.0457 \AA$ (Fig. 2c). This shows how intermolecular F..O contacts provide a significant contribution towards the stabilization of the crystal packing, as already investigated in our recent study in terms of the associated nature and energetics (Sirohiwal et al., 2017b).

The overall molecular arrangement shows the formation of a molecular sheet parallel to the $b c$ plane (Fig. $3 a$ ). This sheet is constructed via the molecular pairs IV $\left(-10.0 \mathrm{~kJ} \mathrm{~mol}^{-1}\right), \mathrm{V}$ $\left(-6.9 \mathrm{KJ} \mathrm{mol}^{-1}\right)$ and VI $\left(-6.0 \mathrm{~kJ} \mathrm{~mol}^{-1}\right)$. It is interesting to note the dominance of the electrostatic (54\%) over the dispersion (46\%) contribution in case of motif IV, which is not to be found in other motifs. A molecular dimeric chain, associated with motif IV, is formed along the crystallographic $c$-axis direction, involving intermolecular $\mathrm{C} 4-\mathrm{H} 4 \cdots \mathrm{O} 1$ and C5-H5 ‥F2 interactions (Table 1). Such dimeric chains are interlinked alternatively along the $b$-axis direction either via molecular pairs $\mathrm{V}$ (involving $\mathrm{C} 4-\mathrm{H} 4 \cdots \mathrm{O} 1$ interactions and $\mathrm{H} \cdot \mathrm{H}$ contacts) or VI (involving bifurcated $\mathrm{C}-\mathrm{H} \cdots \mathrm{F}$ interactions and F...F contacts) related by $c$-glide symmetry. Finally, these parallel molecular sheets are stacked along the $a$-axis direction (Fig. $3 b$ ) via the strongest molecular pairs I. Thus, in the absence of any strong hydrogen bonds, the overall

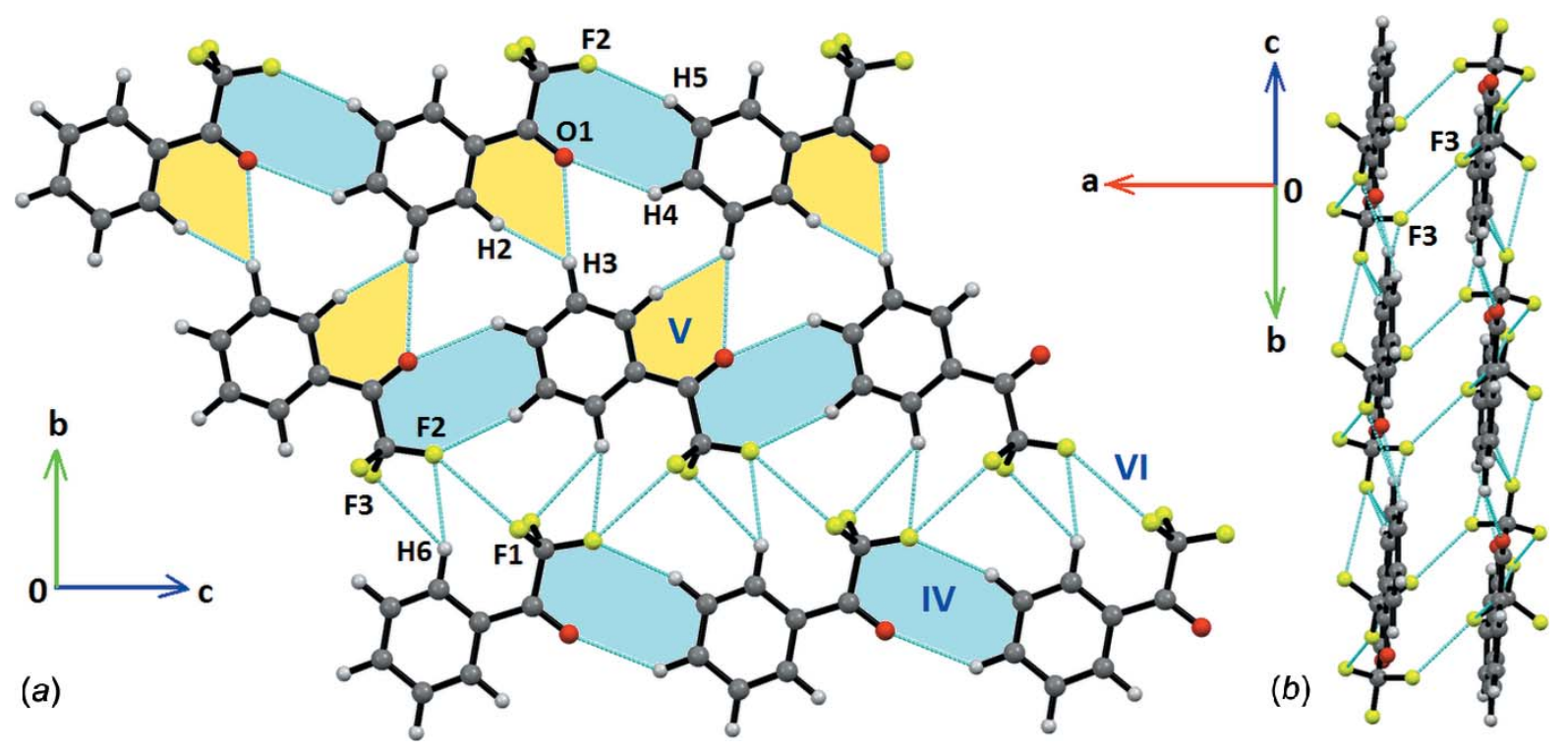

Figure 3

Packing network of TFAP showing $(a)$ the molecular sheet formed via weak interactions in the $b c$ plane and $(b)$ the molecular stacking of two parallel sheets. Weak interactions are shown as cyan dotted lines. 


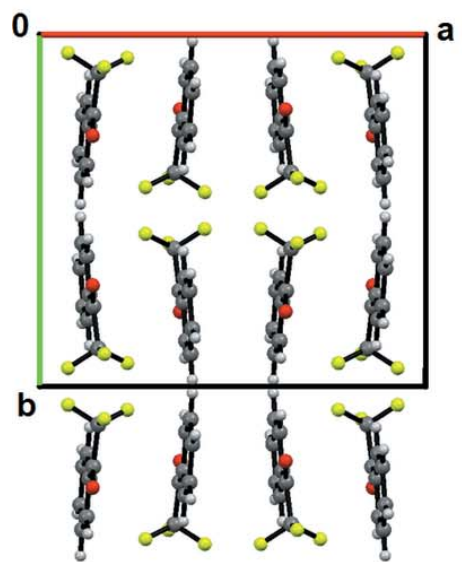

(a)

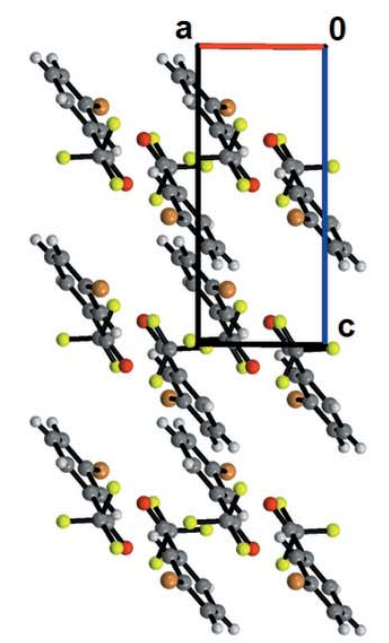

(d)

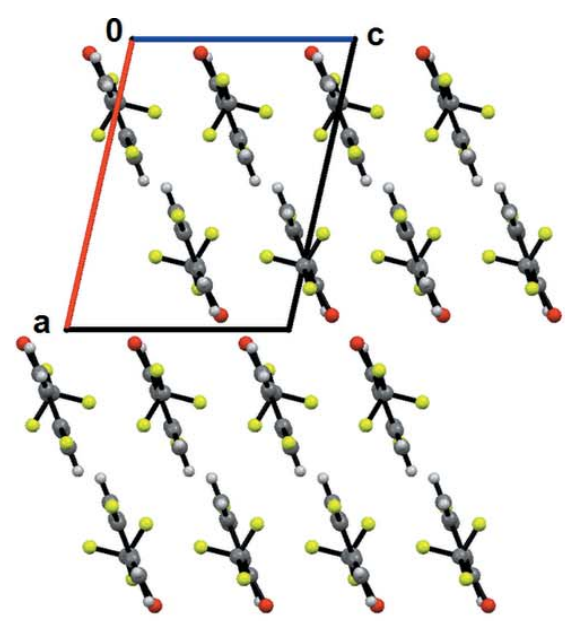

(b)

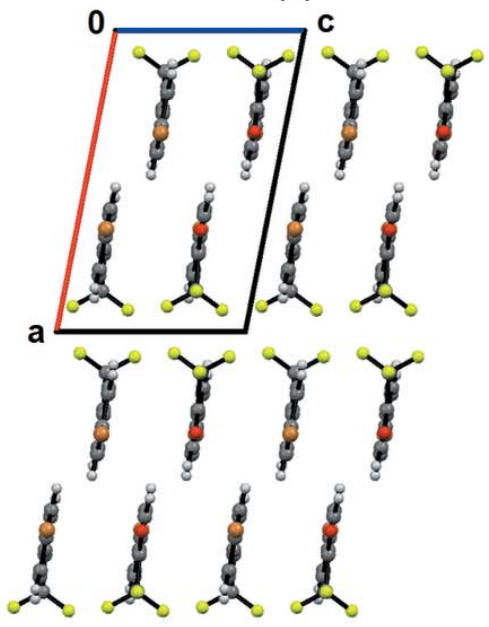

(e)

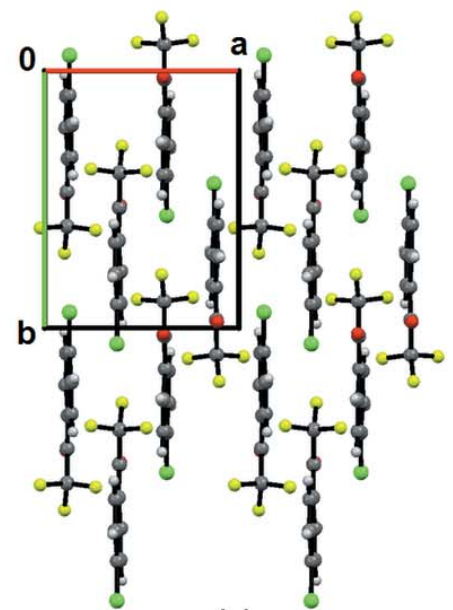

(c)

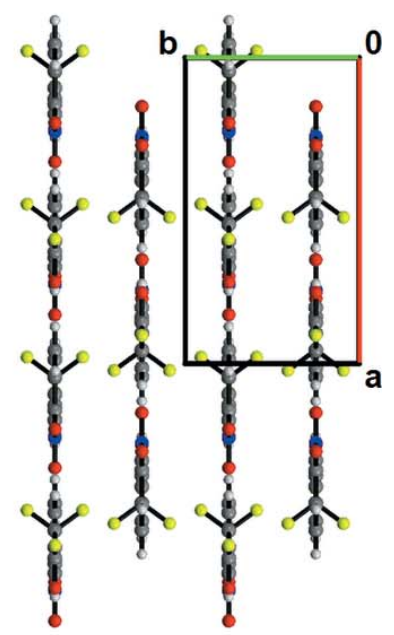

(f)

Figure 4

Molecular assembly in (a) TFAP and substituted TFAPs: $(b)$ 4-fluoro TFAP, $(c)$ 4-chloro TFAP, $(d)$ 4-bromo TFAP, $(e)$ 3-bromo TFAP and $(f)$ 3-nitro TFAP.

crystal packing is stabilized through weak intermolecular interactions.

\section{Database survey}

Most of the substituted TFAPs are also liquid at room temperature and were crystallized via in situ cryocrystallization methods in the absence of OHCD. In particular, the crystal and molecular structures of 4-fluoro TFAP (SIDMAU), 4-chloro TFAP (SIDLUN), 4-bromo TFAP (SIDLOH), 3-bromo TFAP (SIDLEX), and 3-nitro TFAP (SIDLIB) have been obtained and reported (Chopra et al., 2007).

Fig. 4 highlights the similarities and differences of the molecular assemblies for these structures in comparison to unsubstituted TFAP. Interestingly, in most of the cases, the molecular sheets are stacked on each other. The supramolecular assemblies are mainly stabilized via various weak $\mathrm{C}-\mathrm{H} \cdots \mathrm{O} / \mathrm{F} / \mathrm{Cl} / \mathrm{Br} / \mathrm{N}$ interactions and $\mathrm{F} \cdots \mathrm{F}, \mathrm{F} \cdots \mathrm{O}, \mathrm{Br} \cdots \mathrm{O}$,
$\mathrm{Br} \cdots \mathrm{F}$ contacts without the presence of any strong interactions. Upon substitution with $\mathrm{F}, \mathrm{Cl}, \mathrm{Br}$ and $-\mathrm{NO}_{2}$ groups, a molecular chain associated with F...F contacts is observed. In particular, in the case of the para-substituted chloro and bromo analogs, the F ..F chain is quite similar, wherein in the case of the para-substituted fluoro compound, bifurcated F $\cdots F$ contacts are present. Finally, in the case of the $m$-nitro and bromo derivatives, a centrosymmetric, dimeric F...F chain is observed.

\section{Hirshfeld surface analysis}

The Hirshfeld surface analysis was performed using CrystalExplorer3.3 (Turner et al., 2017) to obtain two-dimensional fingerprint maps (Spackman et al., 2002; McKinnon et al., 2007), which help us to understand the crystalline environment in terms of the contributions of various interatomic contacts present in the crystal packing. The $2 \mathrm{D}$ fingerprint plots and the decomposed contributions for different atom- 


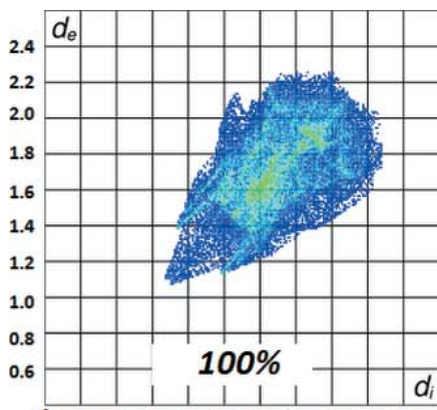

(Å) $\begin{array}{llllllllll}0.6 & 0.8 & 1.0 & 1.2 & 1.4 & 1.6 & 1.8 & 2.0 & 2.2 & 2.4\end{array}$

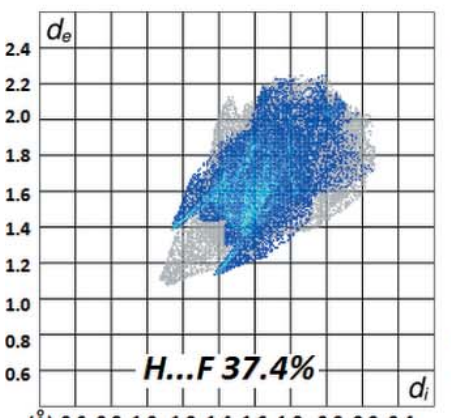

(Å) $\begin{array}{llllllllll}0.6 & 0.8 & 1.0 & 1.2 & 1.4 & 1.6 & 1.8 & 2.0 & 2.2 & 2.4\end{array}$

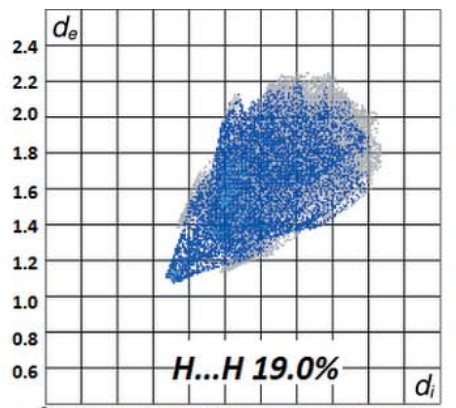

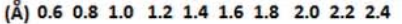

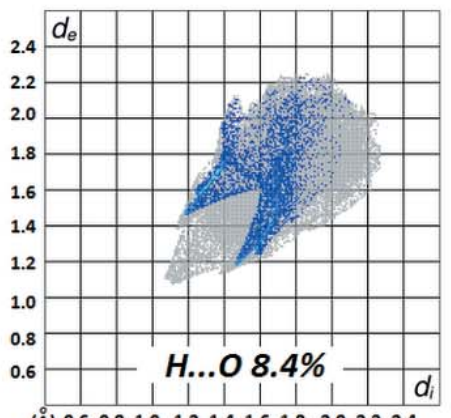

(A) $\begin{array}{llllllllll}0.6 & 0.8 & 1.0 & 1.2 & 1.4 & 1.6 & 1.8 & 2.0 & 2.2 & 2.4\end{array}$

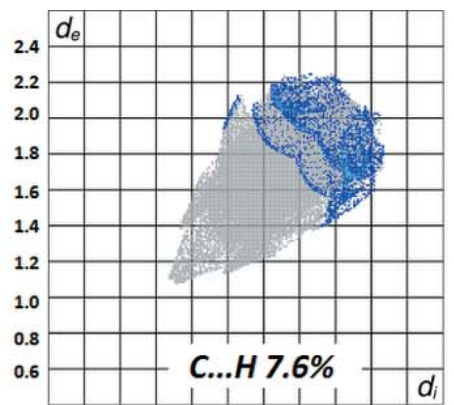

(A) $0.6 \quad 0.8 \quad 1.0 \quad 1.21 .4 \quad 1.6 \quad 1.8 \quad 2.02 .2 \quad 2.4$

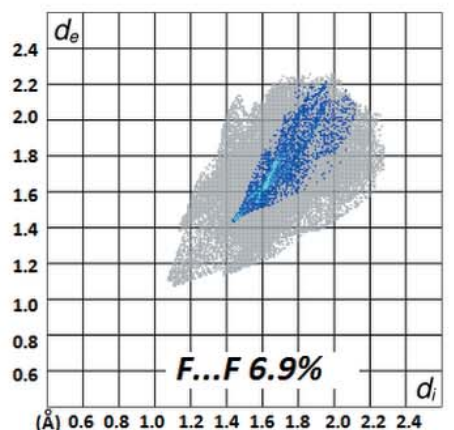

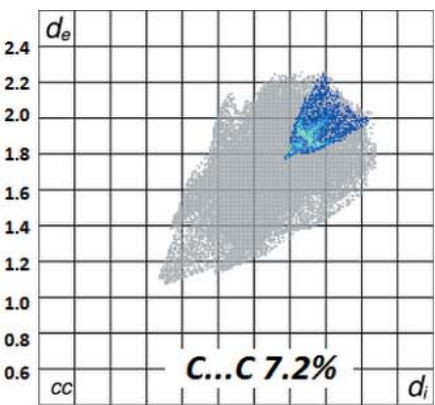

(A) $\begin{array}{llllllllllll}0.6 & 0.8 & 1.0 & 1.2 & 1.4 & 1.6 & 1.8 & 2.0 & 2.2 & 2.4\end{array}$

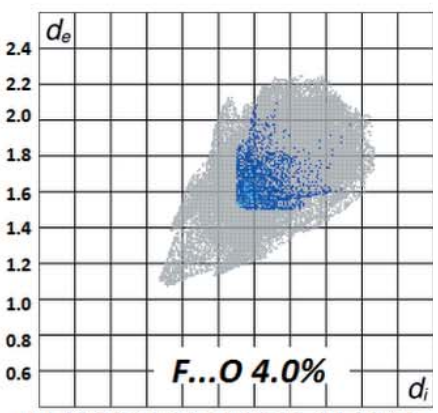

(A) $\begin{array}{lllllllllll}0.6 & 0.8 & 1.0 & 1.2 & 1.4 & 1.6 & 1.8 & 2.0 & 2.2 & 2.4\end{array}$

Figure 5

Two-dimensional fingerprint plots for TFAP, decomposed into contributions from specific atom-atom contacts.

atom contacts in unsubstituted TFAP are shown in Fig. 5. It is observed that the contributions for $\mathrm{H} \cdots \mathrm{F}(37.4 \%)$ and $\mathrm{H} \cdots \mathrm{H}$ $(19.0 \%)$ contacts is relatively high in comparison to the other interatomic contacts. Interestingly, in this case, the fluorine atoms present in the $-\mathrm{CF}_{3}$ group are more involved in the formation of $\mathrm{C}-\mathrm{H} \cdots \mathrm{F}$ interactions rather than the formation of $\mathrm{F} \cdot \mathrm{F}(6.9 \%)$ contacts. The other contacts, namely $\mathrm{C} \cdot \cdots \mathrm{H}$ $(7.6 \%), \mathrm{H} \cdots \mathrm{O}(8.4 \%)$ and $\mathrm{F} \cdots \mathrm{O}(4.0 \%)$ also contribute to the overall crystal packing.

\section{Crystallization, data collection and structure refinement}

The compound TFAP was purchased from Sigma-Aldrich and used for the in situ crystallization experiment without any further purification. The detailed procedure of the crystal-
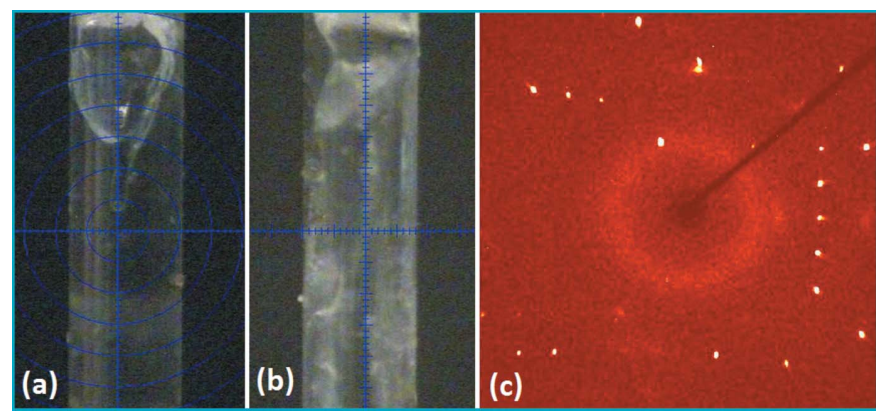

Figure 6

Crystal images at $(a) 200 \mathrm{~K},(b) 110 \mathrm{~K}$, and (c) the diffraction image at $110 \mathrm{~K}$. lization process is already discussed in one of our previous reports (Dey et al., 2016a). Good quality crystals (Fig. 6a) were obtained at $200 \mathrm{~K}$ using a $\mathrm{CO}_{2}$ laser scan utilizing an $\mathrm{OHCD}$ apparatus. Fig. $6 b$ and $c$ depict the crystal at 110 (2) K inside the Lindemann glass capillary and the corresponding diffraction image, respectively. The crystal data, data collection and details on structure refinement are summarized in Table 3. All non-hydrogen atoms were refined anisotropically and the aromatic hydrogen atoms bonded to $\mathrm{C}$ atoms were positioned geometrically and refined using a riding model with $U_{\text {iso }}(\mathrm{H})$ $=1.2 U_{\text {eq }}(\mathrm{C})$ and $\mathrm{C}-\mathrm{H}$ distances of $0.95 \AA$.

\section{Acknowledgements}

DD acknowledges an Institute fellowship. AS would like to thank DST-INSPIRE Scholarship. DC would like to thank IISER Bhopal for the instrumental facility and infrastructure and DST-SERB for research funding.

\section{References}

Allen, F. H. (1986). Acta Cryst. B42, 515-522.

Altomare, A., Cascarano, G., Giacovazzo, C., Guagliardi, A., Burla, M. C., Polidori, G. \& Camalli, M. (1994). J. Appl. Cryst. 27, 435.

Boese, R., Kirchner, M. T., Billups, W. E. \& Norman, L. R. (2003). Angew. Chem. Int. Ed. 42, 1961-1963.

Bruker (2012). APEX2, SAINT and SADABS. Bruker AXS Inc., Madison, Wisconsin, USA.

Cakl, Z., Reimann, S., Schmidt, E., Moreno, A., Mallat, T. \& Baiker, A. (2011). J. Catal. 280, 104-115.

Chopra, D., Thiruvenkatam, V., Manjunath, S. G. \& Guru Row, T. N. (2007). Cryst. Growth Des. 7, 868-874. 
Table 3

Experimental details.

\begin{tabular}{|c|c|}
\hline \multicolumn{2}{|l|}{ Crystal data } \\
\hline Chemical formula & $\mathrm{C}_{8} \mathrm{H}_{5} \mathrm{~F}_{3} \mathrm{O}$ \\
\hline$M_{\mathrm{r}}$ & 174.12 \\
\hline Crystal system, space group & Monoclinic, $C 2 / c$ \\
\hline Temperature $(\mathrm{K})$ & 110 \\
\hline$a, b, c(\AA)$ & $13.8129(3), 12.6034(2), 8.3595$ (2) \\
\hline$\beta\left(^{\circ}\right)$ & $90.396(1)$ \\
\hline$V\left(\AA^{3}\right)$ & $1455.27(5)$ \\
\hline$Z$ & 8 \\
\hline Radiation type & Мo $K \alpha$ \\
\hline$\mu\left(\mathrm{mm}^{-1}\right)$ & 0.16 \\
\hline Crystal size $(\mathrm{mm})$ & $0.30 \times 0.30 \times 0.30$ \\
\hline \multicolumn{2}{|l|}{ Data collection } \\
\hline Diffractometer & Bruker APEXII CCD \\
\hline Absorption correction & $\begin{array}{l}\text { Multi-scan (SADABS; Bruker, } \\
\text { 2012) }\end{array}$ \\
\hline$T_{\min }, T_{\max }$ & $0.697,0.746$ \\
\hline $\begin{array}{l}\text { No. of measured, independent and } \\
\text { observed }[I>2 \sigma(I)] \text { reflections }\end{array}$ & $9958,1045,944$ \\
\hline$R_{\text {int }}$ & 0.014 \\
\hline$(\sin \theta / \lambda)_{\max }\left(\AA^{-1}\right)$ & 0.631 \\
\hline \multicolumn{2}{|l|}{ Refinement } \\
\hline$R\left[F^{2}>2 \sigma\left(F^{2}\right)\right], w R\left(F^{2}\right), S$ & $0.024,0.064,1.08$ \\
\hline No. of reflections & 1045 \\
\hline No. of parameters & 109 \\
\hline $\mathrm{H}$-atom treatment & H-atom parameters constrained \\
\hline$\Delta \rho_{\max }, \Delta \rho_{\min }\left(\mathrm{e} \AA^{-3}\right)$ & $0.19,-0.20$ \\
\hline
\end{tabular}

Computer programs: APEX2 and SAINT (Bruker, 2012), SIR92 (Altomare et al., 1994), SHELXL2016/6 (Sheldrick, 2015), Mercury (Macrae et al., 2008), CIFTAB (Sheldrick, 2008) and PLATON (Spek, 2009).

Choudhury, A. R., Winterton, N., Steiner, A., Cooper, A. I. \& Johnson, K. A. (2005). J. Am. Chem. Soc. 127, 16792-16793.

Dey, D., Bhandary, S., Sirohiwal, A., Hathwar, V. R. \& Chopra, D. (2016a). Chem. Commun. 52, 7225-7228.
Dey, D., Bhandary, S., Thomas, S. P., Spackman, M. A. \& Chopra, D. (2016b). Phys. Chem. Chem. Phys. 18, 31811-31820.

Frisch, M. J., et al. (2009). GAUSSIAN09, Revision D. 01. Gaussian Inc., Wallingford, CT, USA.

Gavezzotti, A. (2003). J. Phys. Chem. B, 107, 2344-2353.

Gavezzotti, A. (2011). New J. Chem. 35, 1360-1368.

Goubert, G., Demers-Carpentier, V., Masini, F., Dong, Y., Lemay, J. C. \& McBreen, P. H. (2011). Chem. Commun. 47, 9113-9115.

Guzmán-Gutiérrez, M. T., Zolotukhin, M. G., Fritsch, D., RuizTreviño, F. A., Cedillo, G., Fregoso-Israel, E., Ortiz-Estrada, C., Chavez, J. \& Kudla, C. (2008). J. Membr. Sci. 323, 379-385.

Limnios, D. \& Kokotos, C. G. (2014a). J. Org. Chem. 79, 42704276.

Limnios, D. \& Kokotos, C. G. (2014b). Chem. Eur. J. 20, 559563.

Macrae, C. F., Bruno, I. J., Chisholm, J. A., Edgington, P. R., McCabe, P., Pidcock, E., Rodriguez-Monge, L., Taylor, R., van de Streek, J. \& Wood, P. A. (2008). J. Appl. Cryst. 41, 466-470.

McKinnon, J. J., Jayatilaka, D. \& Spackman, M. A. (2007). Chem. Commun. 3814-3816.

Sheldrick, G. M. (2008). Acta Cryst. A64, 112-122.

Sheldrick, G. M. (2015). Acta Cryst. C71, 3-8.

Sirohiwal, A., Hathwar, V. R., Dey, D. \& Chopra, D. (2017a). ChemPhysChem, 18, 2859-2863.

Sirohiwal, A., Hathwar, V. R., Dey, D., Regunathan, R. \& Chopra, D. (2017b). Acta Cryst. B73, 140-152.

Spackman, M. A. \& McKinnon, J. J. (2002). CrystEngComm, 4, 378392.

Spek, A. L. (2009). Acta Cryst. D65, 148-155.

Theodorou, A. \& Kokotos, C. G. (2017a). Green Chem. 19, 670674.

Theodorou, A. \& Kokotos, C. G. (2017b). Adv. Synth. Catal. 359, $1577-1581$.

Triandafillidi, I. \& Kokotos, C. G. (2017). Org. Lett. 19, 106-109.

Turner, M. J., McKinnon, J. J., Wolff, S. K., Grimwood, D. J., Spackman, P. R., Jayatilaka, D. \& Spackman, M. A. (2017). CrystalExplorer17, University of Western Australia.http://hirshfeldsurface.net 


\section{supporting information}

Acta Cryst. (2018). E74, 607-612 [https://doi.org/10.1107/S2056989017016590]

\section{Crystal packing analysis of in situ cryocrystallized 2,2,2-trifluoroacetophenone}

\section{Dhananjay Dey, Abhishek Sirohiwal and Deepak Chopra}

Computing details

Data collection: APEX2 (Bruker, 2012); cell refinement: SAINT (Bruker, 2012); data reduction: SAINT (Bruker, 2012); program(s) used to solve structure: SIR92 (Altomare et al., 1994); program(s) used to refine structure: SHELXL2016/6 (Sheldrick, 2015); molecular graphics: Mercury (Macrae et al., 2008); software used to prepare material for publication: CIFTAB (Sheldrick, 2008) and PLATON (Spek, 2009).

\section{2,2,2-Trifluoroacetophenone}

Crystal data

$$
\begin{aligned}
& \mathrm{C}_{8} \mathrm{H}_{5} \mathrm{~F}_{3} \mathrm{O} \\
& M_{r}=174.12 \\
& \text { Monoclinic, } C 2 / c \\
& a=13.8129(3) \AA \\
& b=12.6034(2) \AA \\
& c=8.3595(2) \AA \\
& \beta=90.396(1)^{\circ} \\
& V=1455.27(5) \AA^{3} \\
& Z=8
\end{aligned}
$$

Data collection

\section{Bruker APEXII CCD} diffractometer

Radiation source: fine focus sealed tube $\omega$ scans Absorption correction: multi-scan

(SADABS; Bruker, 2008)

$T_{\min }=0.697, T_{\max }=0.746$

9958 measured reflections

\section{Refinement}

Refinement on $F^{2}$

Least-squares matrix: full $R\left[F^{2}>2 \sigma\left(F^{2}\right)\right]=0.024$ $w R\left(F^{2}\right)=0.064$ $S=1.08$ 1045 reflections 109 parameters 0 restraints
$F(000)=704$

$D_{\mathrm{x}}=1.589 \mathrm{Mg} \mathrm{m}^{-3}$

Mo $K \alpha$ radiation, $\lambda=0.71073 \AA$

Cell parameters from 5549 reflections

$\theta=2.2-30.2^{\circ}$

$\mu=0.16 \mathrm{~mm}^{-1}$

$T=110 \mathrm{~K}$

Block, colorless

$0.30 \times 0.30 \times 0.30 \mathrm{~mm}$

1045 independent reflections 944 reflections with $I>2 \sigma(I)$

$R_{\text {int }}=0.014$

$\theta_{\text {max }}=26.7^{\circ}, \theta_{\min }=2.2^{\circ}$

$h=-17 \rightarrow 17$

$k=-15 \rightarrow 15$

$l=-5 \rightarrow 5$

Hydrogen site location: inferred from neighbouring sites

$\mathrm{H}$-atom parameters constrained

$w=1 /\left[\sigma^{2}\left(F_{\mathrm{o}}^{2}\right)+(0.0305 P)^{2}+0.8314 P\right]$

where $P=\left(F_{\mathrm{o}}{ }^{2}+2 F_{\mathrm{c}}{ }^{2}\right) / 3$

$(\Delta / \sigma)_{\max }<0.001$

$\Delta \rho_{\max }=0.19 \mathrm{e} \AA^{-3}$

$\Delta \rho_{\min }=-0.20 \mathrm{e} \AA^{-3}$ 


\section{Special details}

Geometry. All esds (except the esd in the dihedral angle between two 1.s. planes) are estimated using the full covariance matrix. The cell esds are taken into account individually in the estimation of esds in distances, angles and torsion angles; correlations between esds in cell parameters are only used when they are defined by crystal symmetry. An approximate (isotropic) treatment of cell esds is used for estimating esds involving l.s. planes.

Fractional atomic coordinates and isotropic or equivalent isotropic displacement parameters $\left(\hat{A}^{2}\right)$

\begin{tabular}{lllll}
\hline & $x$ & $y$ & $z$ & $U_{\text {iso }} / U_{\text {eq }}$ \\
\hline F1 & $0.27357(5)$ & $0.43371(5)$ & $0.83259(12)$ & $0.0310(3)$ \\
F2 & $0.33321(6)$ & $0.40770(6)$ & $1.06711(16)$ & $0.0376(4)$ \\
F3 & $0.42716(5)$ & $0.44771(5)$ & $0.87193(13)$ & $0.0331(3)$ \\
O1 & $0.36355(6)$ & $0.21263(7)$ & $0.98806(15)$ & $0.0268(3)$ \\
C4 & $0.39488(8)$ & $0.16370(10)$ & $0.3960(2)$ & $0.0278(5)$ \\
H4 & 0.402903 & 0.138083 & 0.290060 & $0.033^{*}$ \\
C5 & $0.38764(9)$ & $0.27193(10)$ & $0.4248(2)$ & $0.0273(5)$ \\
H5 & 0.390579 & 0.320406 & 0.337898 & $0.033^{*}$ \\
C6 & $0.37625(8)$ & $0.30955(9)$ & $0.5781(2)$ & $0.0223(5)$ \\
H6 & 0.371252 & 0.383735 & 0.596420 & $0.027^{*}$ \\
C1 & $0.37202(7)$ & $0.23921(9)$ & $0.7068(2)$ & $0.0176(5)$ \\
C7 & $0.36188(7)$ & $0.27209(9)$ & $0.8742(2)$ & $0.0200(5)$ \\
C8 & $0.34856(9)$ & $0.39204(9)$ & $0.9128(3)$ & $0.0241(5)$ \\
C3 & $0.39028(9)$ & $0.09306(9)$ & $0.5237(2)$ & $0.0259(5)$ \\
H3 & 0.395028 & 0.018927 & 0.504787 & $0.031^{*}$ \\
C2 & $0.37893(8)$ & $0.12990(9)$ & $0.6766(2)$ & $0.0235(5)$ \\
H2 & 0.375707 & 0.081052 & 0.762999 & $0.028^{*}$ \\
& & & &
\end{tabular}

Atomic displacement parameters $\left(\AA^{2}\right)$

\begin{tabular}{lllllll}
\hline & $U^{11}$ & $U^{22}$ & $U^{33}$ & $U^{12}$ & $U^{13}$ & $U^{33}$ \\
\hline F1 & $0.0323(4)$ & $0.0267(4)$ & $0.0339(10)$ & $0.0079(3)$ & $0.0017(4)$ & $0.0015(3)$ \\
F2 & $0.0604(5)$ & $0.0314(4)$ & $0.0210(13)$ & $0.0015(3)$ & $0.0051(5)$ & $-0.0069(4)$ \\
F3 & $0.0336(4)$ & $0.0239(3)$ & $0.0420(9)$ & $-0.0065(3)$ & $0.0030(4)$ & $-0.0046(3)$ \\
O1 & $0.0382(5)$ & $0.0281(4)$ & $0.0142(12)$ & $-0.0003(3)$ & $0.0004(4)$ & $0.0047(5)$ \\
C4 & $0.0263(6)$ & $0.0403(7)$ & $0.0169(16)$ & $-0.0026(5)$ & $0.0001(6)$ & $-0.0063(7)$ \\
C5 & $0.0330(6)$ & $0.0347(7)$ & $0.0141(19)$ & $-0.0028(5)$ & $0.0007(6)$ & $0.0079(7)$ \\
C6 & $0.0281(6)$ & $0.0234(6)$ & $0.0156(18)$ & $-0.0001(4)$ & $0.0004(6)$ & $0.0031(6)$ \\
C1 & $0.0193(5)$ & $0.0217(5)$ & $0.0118(17)$ & $-0.0007(4)$ & $-0.0007(5)$ & $0.0013(6)$ \\
C7 & $0.0207(5)$ & $0.0220(6)$ & $0.0171(17)$ & $-0.0011(4)$ & $-0.0002(5)$ & $0.0032(7)$ \\
C8 & $0.0296(6)$ & $0.0248(6)$ & $0.018(2)$ & $-0.0003(4)$ & $0.0021(6)$ & $-0.0021(6)$ \\
C3 & $0.0338(6)$ & $0.0253(6)$ & $0.0187(17)$ & $-0.0013(4)$ & $0.0001(6)$ & $-0.0048(7)$ \\
C2 & $0.0293(6)$ & $0.0215(6)$ & $0.0197(18)$ & $-0.0011(4)$ & $-0.0012(6)$ & $0.0026(6)$ \\
& & & & & &
\end{tabular}

Geometric parameters $\left(\AA,{ }^{o}\right)$

\begin{tabular}{llll}
\hline $\mathrm{F} 1-\mathrm{C} 8$ & $1.3373(17)$ & $\mathrm{C} 6-\mathrm{C} 1$ & $1.396(2)$ \\
$\mathrm{F} 2-\mathrm{C} 8$ & $1.324(2)$ & $\mathrm{C} 6-\mathrm{H} 6$ & 0.9500 \\
$\mathrm{~F} 3-\mathrm{C} 8$ & $1.3389(15)$ & $\mathrm{C} 1-\mathrm{C} 2$ & $1.4040(15)$
\end{tabular}




\begin{tabular}{|c|c|c|c|}
\hline $\mathrm{O} 1-\mathrm{C} 7$ & $1.2112(18)$ & $\mathrm{C} 1-\mathrm{C} 7$ & $1.467(2)$ \\
\hline $\mathrm{C} 4-\mathrm{C} 5$ & $1.3888(19)$ & $\mathrm{C} 7-\mathrm{C} 8$ & $1.5569(16)$ \\
\hline $\mathrm{C} 4-\mathrm{C} 3$ & $1.392(2)$ & $\mathrm{C} 3-\mathrm{C} 2$ & $1.370(2)$ \\
\hline $\mathrm{C} 4-\mathrm{H} 4$ & 0.9500 & $\mathrm{C} 3-\mathrm{H} 3$ & 0.9500 \\
\hline $\mathrm{C} 5-\mathrm{C} 6$ & $1.377(2)$ & $\mathrm{C} 2-\mathrm{H} 2$ & 0.9500 \\
\hline $\mathrm{C} 5-\mathrm{H} 5$ & 0.9500 & & \\
\hline $\mathrm{C} 5-\mathrm{C} 4-\mathrm{C} 3$ & $119.46(17)$ & $\mathrm{C} 1-\mathrm{C} 7-\mathrm{C} 8$ & $118.93(13)$ \\
\hline $\mathrm{C} 5-\mathrm{C} 4-\mathrm{H} 4$ & 120.3 & $\mathrm{~F} 2-\mathrm{C} 8-\mathrm{F} 1$ & $107.54(12)$ \\
\hline $\mathrm{C} 3-\mathrm{C} 4-\mathrm{H} 4$ & 120.3 & $\mathrm{~F} 2-\mathrm{C} 8-\mathrm{F} 3$ & $107.82(12)$ \\
\hline $\mathrm{C} 6-\mathrm{C} 5-\mathrm{C} 4$ & $120.53(15)$ & $\mathrm{F} 1-\mathrm{C} 8-\mathrm{F} 3$ & $107.05(12)$ \\
\hline $\mathrm{C} 6-\mathrm{C} 5-\mathrm{H} 5$ & 119.7 & $\mathrm{~F} 2-\mathrm{C} 8-\mathrm{C} 7$ & $111.48(12)$ \\
\hline $\mathrm{C} 4-\mathrm{C} 5-\mathrm{H} 5$ & 119.7 & $\mathrm{~F} 1-\mathrm{C} 8-\mathrm{C} 7$ & $111.71(12)$ \\
\hline $\mathrm{C} 5-\mathrm{C} 6-\mathrm{C} 1$ & $120.32(13)$ & $\mathrm{F} 3-\mathrm{C} 8-\mathrm{C} 7$ & $111.03(11)$ \\
\hline $\mathrm{C} 5-\mathrm{C} 6-\mathrm{H} 6$ & 119.8 & $\mathrm{C} 2-\mathrm{C} 3-\mathrm{C} 4$ & $120.33(13)$ \\
\hline $\mathrm{C} 1-\mathrm{C} 6-\mathrm{H} 6$ & 119.8 & $\mathrm{C} 2-\mathrm{C} 3-\mathrm{H} 3$ & 119.8 \\
\hline $\mathrm{C} 6-\mathrm{C} 1-\mathrm{C} 2$ & $118.78(16)$ & $\mathrm{C} 4-\mathrm{C} 3-\mathrm{H} 3$ & 119.8 \\
\hline $\mathrm{C} 6-\mathrm{C} 1-\mathrm{C} 7$ & $124.10(12)$ & $\mathrm{C} 3-\mathrm{C} 2-\mathrm{C} 1$ & $120.58(14)$ \\
\hline $\mathrm{C} 2-\mathrm{C} 1-\mathrm{C} 7$ & $117.11(13)$ & $\mathrm{C} 3-\mathrm{C} 2-\mathrm{H} 2$ & 119.7 \\
\hline $\mathrm{O} 1-\mathrm{C} 7-\mathrm{C} 1$ & $124.96(12)$ & $\mathrm{C} 1-\mathrm{C} 2-\mathrm{H} 2$ & 119.7 \\
\hline $\mathrm{O} 1-\mathrm{C} 7-\mathrm{C} 8$ & $116.10(16)$ & & \\
\hline $\mathrm{C} 3-\mathrm{C} 4-\mathrm{C} 5-\mathrm{C} 6$ & $0.17(18)$ & $\mathrm{C} 1-\mathrm{C} 7-\mathrm{C} 8-\mathrm{F} 2$ & $175.26(9)$ \\
\hline $\mathrm{C} 4-\mathrm{C} 5-\mathrm{C} 6-\mathrm{C} 1$ & $0.12(17)$ & $\mathrm{O} 1-\mathrm{C} 7-\mathrm{C} 8-\mathrm{F} 1$ & $-125.49(14)$ \\
\hline $\mathrm{C} 5-\mathrm{C} 6-\mathrm{C} 1-\mathrm{C} 2$ & $-0.42(16)$ & $\mathrm{C} 1-\mathrm{C} 7-\mathrm{C} 8-\mathrm{F} 1$ & $54.91(16)$ \\
\hline $\mathrm{C} 5-\mathrm{C} 6-\mathrm{C} 1-\mathrm{C} 7$ & $178.79(10)$ & $\mathrm{O} 1-\mathrm{C} 7-\mathrm{C} 8-\mathrm{F} 3$ & $115.10(15)$ \\
\hline $\mathrm{C} 6-\mathrm{C} 1-\mathrm{C} 7-\mathrm{O} 1$ & $-175.62(11)$ & $\mathrm{C} 1-\mathrm{C} 7-\mathrm{C} 8-\mathrm{F} 3$ & $-64.50(17)$ \\
\hline $\mathrm{C} 2-\mathrm{C} 1-\mathrm{C} 7-\mathrm{O} 1$ & $3.60(16)$ & $\mathrm{C} 5-\mathrm{C} 4-\mathrm{C} 3-\mathrm{C} 2$ & $-0.15(18)$ \\
\hline $\mathrm{C} 6-\mathrm{C} 1-\mathrm{C} 7-\mathrm{C} 8$ & $3.94(15)$ & $\mathrm{C} 4-\mathrm{C} 3-\mathrm{C} 2-\mathrm{C} 1$ & $-0.15(17)$ \\
\hline $\mathrm{C} 2-\mathrm{C} 1-\mathrm{C} 7-\mathrm{C} 8$ & $-176.84(10)$ & $\mathrm{C} 6-\mathrm{C} 1-\mathrm{C} 2-\mathrm{C} 3$ & $0.43(16)$ \\
\hline $\mathrm{O} 1-\mathrm{C} 7-\mathrm{C} 8-\mathrm{F} 2$ & $-5.15(14)$ & $\mathrm{C} 7-\mathrm{C} 1-\mathrm{C} 2-\mathrm{C} 3$ & $-178.83(10)$ \\
\hline
\end{tabular}

Hydrogen-bond geometry $\left(\AA,{ }^{\circ}\right)$

\begin{tabular}{lllll}
\hline$D-\mathrm{H} \cdots A$ & $D-\mathrm{H}$ & $\mathrm{H} \cdots A$ & $D \cdots A$ & $D-\mathrm{H} \cdots A$ \\
\hline $\mathrm{C} 6-\mathrm{H} 6 \cdots \mathrm{F} 1$ & 0.95 & 2.48 & $3.004(2)$ & 115 \\
$\mathrm{C} 6-\mathrm{H} 6 \cdots \mathrm{F} 3$ & 0.95 & 2.55 & $3.088(2)$ & 116 \\
$\mathrm{C} 5-\mathrm{H} 5 \cdots \mathrm{F} 2^{\mathrm{i}}$ & 0.95 & 2.63 & $3.522(2)$ & 156 \\
$\mathrm{C} 4-\mathrm{H} 4 \cdots{ }^{\mathrm{O}} 1^{\mathrm{i}}$ & 0.95 & 2.74 & $3.490(2)$ & 136 \\
$\mathrm{C} 6-\mathrm{H} 6 \cdots \mathrm{F}^{2 i}$ & 0.95 & 2.69 & $3.614(2)$ & 163 \\
$\mathrm{C} 6-\mathrm{H} 6 \cdots \mathrm{F}^{\mathrm{ii}}$ & 0.95 & 2.94 & $3.584(2)$ & 126 \\
$\mathrm{C} 5-\mathrm{H} 5 \cdots \mathrm{F} 3{ }^{\mathrm{ii}}$ & 0.95 & 2.98 & $3.603(2)$ & 124 \\
$\mathrm{C} 3-\mathrm{H} 3 \cdots{ }^{\mathrm{iii}}$ & 0.95 & 2.95 & $3.882(2)$ & 166 \\
\hline
\end{tabular}

Symmetry codes: (i) $x, y, z-1$; (ii) $x,-y+1, z-1 / 2$; (iii) $x,-y, z-1 / 2$. 